\title{
Analisis Strategi Bisnis PT. Centrepark Citra Corpora di Teras Kota Mall Tangerang Selatan
}

\section{Business Strategy Analysis of PT. Centrepark Citra Corpora in Teras Kota Mall, South Tangerang}

\author{
Iwan Asmadi ${ }^{1}$, Wilhamdoni ${ }^{2}$ \\ ${ }^{1}$ Universitas Bina Saran Informatika, Indonesia \\ ${ }^{2}$ STIE Triguna, Indonesia \\ ${ }^{1}$ iwan.iad@bsi.ac.id, ${ }^{2}$ rusnanwilhamdoni@yahoo.co.id
}

\begin{abstract}
Abstrak
Penelitian ini menggunakan metode deskriptif kualitatif melalui kombinasi teknik observasi, wawancara, dan kuesioner untuk semua karyawan perusahaan. Berdasarkan hasil analisis disimpulkan kebijakan atau keputusan terbaik yang akan diambil oleh perusahaan dalam rangka memaksimalkan faktor faktor kekuatan dan peluang serta mengatasi ancaman yang kemungkinan akan terjadi dan menemukan rumusan dalam mengatasi kelemahan perusahaan. Dalam matriks IFE adalah 2,94 dan matriks EFE adalah 2,88. Menurut skala 4, posisi internal dan eksternal sebenarnya tidak kuat karena nilai $<3$ adalah nilai yang kuat. Namun, posisi yang lemah ini cenderung kuat mengingat jaraknya tidak terlalu jauh untuk mencapai nilai 3. Dalam matriks IFE perusahaan tidak berada dalam posisi yang aman dan tidak stabil sehingga perlu meminimalkan kelemahan dan ancaman. Dalam matriks EFE, perusahaan juga harus memaksimalkan kekuatan dan peluang yang ada sehingga posisi perusahaan berada dalam posisi yang lebih baik. Dalam matriks CPM yang menganalisis profil persaingan di mana posisi perusahaan sedikit lebih unggul daripada pesaingnya, PT. Centrepark Citra Corpora dari 3,52, PT. Secure Parking Indonesia bernilai 3,30, Parkir VIP 2,86. Hal ini mengharuskan perusahaan untuk mencoba memaksimalkan kemampuan mereka untuk memenangkan persaingan karena kecenderungan untuk dapat menyalip dan mengalahkan satu sama lain secara terbuka yang tercermin dalam jarak yang sangat rendah antara pesaing.
\end{abstract}

Kata Kunci: Strategi Bisnis; Analisis Faktor Internal; Analisis Faktor Eksternal; Analisis SWOT

\begin{abstract}
This research uses Qualitative Descriptive method through a combination of observation, interview, and questionnaire techniques for all company employees. From the analysis concluded the best policy or decision that will be taken by the company in order to maximize the factors of strength and opportunity factors and overcome threats that are likely to occur and find formulations in overcoming company weaknesses. In the IFE matrix is 2.94 and the EFE matrix is 2.88. According to scale 4, the internal and external positions are actually not strong because the value $<3$ is a strong value. However, this weak position tends to be strong considering the distance is not too far to reach value 3. In the IFE matrix the company is not in a safe and unstable position so it needs to minimize weaknesses and threats. In the EFE matrix, companies must also maximize the strengths and opportunities that exist so that the company's position is in a better position.In the CPM matrix that analyzes the competition profile where the position of the company is slightly superior to that of its competitors, PT. Centrepark Citra Corpora of 3.52, PT. Secure Parking Indonesia is value 3.30, VIP Parking is 2.86. This requires companies to try to maximize their ability to win the competition because of the tendency to be able to overtake and beat each other wide open which is reflected in the very low distance between competitors.
\end{abstract}

Keywords: Business Strategy; Internal Factor Analysis; External Factor Analysis; SWOT Analysis

\section{PENDAHULUAN}

PT. Centrepark Citra Corpora sebagai objek penelitian ini adalah perusahaan jasa perparkiran yang berdiri pada tahun November 2009, pada saat ini telah memiliki cabang 250 
lokasi atau outlet di 34 kota-kota besar diseluruh Indonesia dan telah memiliki karyawan lebih dari 5.000 orang.

Pada awal mulanya berdiri perusahaan ini dilatar belakangi oleh pemikiran presiden direktur (pendiri perusahaan) yakni Charles R Oentomo yang pada awalnya juga karyawan perusahaan jasa perparkiran berpikir bahwa mengapa perusahaan jasa perparkiran yang ada di Indonesia terlalu lama dikuasai oleh pihak asing. Seperti perusahaan parkir Secure parking dari Australia dan ISS parking dari Denmark. Sehingga terbesit dan selanjutnya direalisasikan oleh beliau untuk mendirikan suatu perusahaan yang sejenis. Bersama teman seperjuangan akhirnya Charles R Oentomo berhasil mendirikan perusahaan yang bergerak dibidang jasa perparkiran yang terintegritas dalam Management Parking System.

Setelah menjalani operasional selama 8 tahun sejak berdiri, PT. Centrepark Citra Corpora berhasil menempati posisi kedua dibawah pemegang tertinggi perusahaan perpakiran yakni Secure Parking Indonesia. Hal ini merupakan pencapaian yang luar biasa mengingat PT. Centrepark Citra Corpora masih seumur jagung apabila dibandingkan dengan ISS Parking 26 tahun dan sang penguasa pasar Secure Parking 25 tahun sejak beroperasi di Indonesia. Secara Matematis, posisi PT. Centrepark Citra Corpora berada pada tempat yang belum aman karena bisa saja pesaing (competitor) dibawahnya baik lokal maupun luar negeri menyalip untuk menjadi lebih baik dari PT. Centrepark Citra Corpora. Berdasarkan latar belakang tersebut dibutuhkan Strategi yang tepat guna mewujudkan tujuan perusahaan jangka pendek dan jangka panjang untuk menjadi perusahaan yang tumbuh dan berkembang dikanca dunia perparkiran serta memperoleh dan mempertahankan keunggulan bersaing terhadap pesaing yang selalu berusaha untuk lebih baik.

Menurut Swastha \& Sukotjo (2010:11) Bisnis adalah semua aspek kegiatan untuk menyalurkan barang-barang melalui saluran produktif dari membeli bahan mentah sampai menjual menjadi barang jadi.

Menurut David (2016), Manajemen Strategi adalah ilmu yang mengenai perumusan, pelaksanaan dan evaluasi keputusan-keputusan lintas fungsi yang memungkinkan organisasi mencapai tujuannya. Menurut Husein Umar, manajemen strategi adalah suatu seni dan ilmu dalam hal pembuatan (furmulating), penerapan (implementing), dan evaluasi (evaluating) keputusan-keputusan strategis yang antar fungsi yang memungkinkan sebuah organisasi mencapai tujuannya pada masa mendatang. 
Analisis Lingkungan Eksternal

Menurut Fred R (2016) Faktor utama eksternal yang penting untuk mencapai tujuan jangka panjang maupun tahunan, terukur dan hierarkis dalam pengertian bahwa beberapa akan berkaitan dengan perusahaan secara keseluruhan dan yang lain akan berfokus pada fungsional atau divisional tertutup. Umumnya akhir dari kegiatan eksternal paling penting karena harus dikomunikasikan dan didistribusikan secara luas dalam suatu organisasi. Berikut ini yang mempengaruhi lingkungan eksternal sebagai berikut :

a. Kekuatan ekonomi

b. Kekuatan Sosial, Budaya, Demografi dan Lingkungan

c. Kekuatan politik, Pemerintah dan Hukum

d. Kekuatan Teknologi

e. Kekuatan Kompetitif

1. Analisis Lingkungan Internal

Pada lingkungan internal suatu perusahaan yang menjadi perhatiann yakni aspek kekuatan dan aspek kelemahan. Tindakan yang akan diambil terhadap aspek kekuatan dan aspek kelemahan merupakan bagian dari fungsi manajemen dalam menjalankan tugas yang ditugaskan, dalam rangka mencapai target, dapat selalu eksis didunia perusahaan yang digeluti.

Analisis SWOT

Menurut Purwanto, Irwan (2010), SWOT adalah kekuatan (Streengths) - kelemahan (Weaknesses) - Peluang (Opportunities) - Ancaman (Threats).

a. SO (Kekuatan - Peluang)

Strategi yang digunakan perusahaan dengan menmaksimalkan kekuatan demi mendapatkan peluang yang ada.

b. WO (Kelemahan - Peluang)

Strategi yang digunakan perusahaan adalah dengan menimalisir atau menghilangkan kelemahan untuk mendapatkan peluang yang ada.

c. ST (Kekuatan - Ancaman)

Strategi yang digunakan perusahaan adalah dengan meminimalisir atau menghilangkan ancaman dengan mengoptimalkan kekuatan yang ada.

d. WT (Kelemahan - Ancaman)

Strategi yang digunakan perusahaan adalah dengan menimalisir atau menghilangkan kelemahan untuk menimalisir ancaman. 


\section{METODOLOGI PENELITIAN}

Penelitian ini di lakukan di perusahaan yang bergerak dibidang jasa perparkiran yang dikelola secara modern dan profesional yakni PT. Centrepark Citra Corpora cabang Teras Kota Mall sebagai pengelolah gedung di BSD city kota Tangerang Selatan. Subyek penelitian ini adalah data yang didapat dari hasil wawancara atau observasi ditempat penelitian yang melibatkan karyawan, staff kantor dan administrasi serta pimpinan lokasi sedangkan objek pada penelitian ini adalah perusaahaan tempat dimana penelitian dilakukan. Dalam hal ini objeknya adalah PT. Centrepark Citra Corpora di Teras Kota Mall cabang BSD City kota Tangerang Selatan.

\section{Teknik Analisis Data}

Menurut David (2016), Metode analisis yang digunakan pada konsep kerja perumusan strategi meliputi 3 tahap yakni tahap input data: matrik Internal Factor Evaluation (IFE), External Factor Evaluation (EFE) dan Competitive Profile Matrix (CPM), tahap analisis data: matrik SWOT, matrik Internal - External (IE) dan matrik Grand Strategy (GS) dan tahap kesimpulan: matrik Quantitative Strategy Planning Matrix (QSPM).

Teknik analisis data ini mempermudah penelitian dan mempermudah pemahaman pembaca yang tidak terlibat langsung dalam penelitian. Alur dari tahap tersebut membentuk kerangka kerja dari awal sampai akhir penelitian yaitu pemilihan kebijakan strategi yang terbaik, efektif dan efisien.

\section{HASIL DAN PEMBAHASAN}

\section{Matrik Internal Factor Evaluation (IFE)}

Berdasarkan data hasil dari matrik IFE, setelah dilakukan pembobotan dan pemeringkatan dan penjumlahan menghasilkan data yang mencerminkan kekuatan dan posisi dari PT. Centrepark Citra Corpora Teras Kota Mall Tangerang Selatan. Diketahui jumlah nilai yang dibobot untuk PT. Centrepark Citra Corpora yakni sebesar 2,94.

Nilai ini menunjukan bahwa posisi perusahaan pada posisi yang lemah namun cenderung kuat. Kecenderungkuatan ini dikarenakan untuk pada posisi yang kuat hanya perlu meningkatkan sebesar 0,06 saja. Namun perusahaan harus berupaya semaksimal mungkin karena posisi tersebut masih pada posisi yang belum aman dan 
labil dengan memperkuat internal perusahaan dapat meminimalisir ancaman dari eksternal perusahaan..

\section{Matrik External Factor Evaluation (EFE)}

Berdasarkan dari data tabel hasil matrik EFE, diketahui jumlah nilai yang dibobot untuk PT. Centrepark Citra Corpora yakni 2,88. Nilai ini menunjukan posisi PT Centrepark Citra Corpora yang lemah cenderung kuat dari faktor eksternal perusahaan. Pada posisi ini perusahaan juga belum pada posisi yang aman dan masih labil. Melihat dari data diatas adanya ancaman akan perebutan lahan parkir dari eksternal perusahaan mengharuskan perusahaan meminimalisir ancaman dan memaksimalkan peluang yang ada.

Matrik Competitive Profile Matrix (CPM)

Matrik CPM (Profil persaingan) yang digunakan untuk mengidentifikasi pesaing-pesaing PT. Centrepark Citra Corpora. Dampak dari persaingan ini yakni kepengolahan parkir di Teras Kota Mall. Jadi persaingan disini persaingan profil terbaik guna dapat dipercaya dalam pengelolahannya. Pesaing tersebut berdasarkan hasil penelitian dan wawancara yakni PT. Secure Parking Indonesia sebagai pemegang perparkiran utama di Indonesia yang merupakan perusahaan dari Australia dan VIP Parking merupakan pendatang baru yang dikelolah oleh dinas perhubungan kota Tangerang Selatan.

Berdasarkan dari data hasil penilaian matrik CPM diatas, setiap perusahaan saling bersaing ketat terhadap pesaing-pesaing perusahaan. PT. Centrepark Citra Corpora bersaing ketat dengan PT. Secure Parking Indonesia sama-sama kuat yakni 3,52 terhadap 3,30 selisih 0,22. Sedangkan VIP Parking berada posisi lemah dengan nilai 2,86 akan tetapi untuk bisa berada posisi yang kuat yakni 3, VIP Parking hanya kurang 0,14 saja dalam upaya menjadi lebih unggul terhadap para pesaingnya. Melihat persaingan yang sangat ketat, PT. Centrepark Citra Corpora harus dapat memilih strategi bisnis yang tepat agar bisa bersaing dan menjadi nomor satu.

\section{Matrik SWOT}

Matrik SWOT adalah matrik yang menganalisis aspek internal (kekuatan dan kelemahan) dan aspek eksternal (peluang dan ancaman) selanjutnya perusahaan menentukan strategi yang tepat yang pada prinsifnya menjaga peluang yang ada dengan memaksimalkan kekuatan dan mengatasi ancaman dengan mengatasi kelemahan yang pada internal perusahaan PT. Centrepark Citra Corpora. 
Berikut ini adalah hasil dari analisis SWOT dari input data yang didapat dari wawancara pada tahap penelitian di lokasi penelitian. dari data berikut dapat disimpulkan kebijakan strategi yang dapat digunakan perusahaan.

\section{Tabel 4 Analisis SWOT}

\begin{tabular}{|c|c|}
\hline Kekuatan - & Kelemahan - Weaknesses \\
\hline $\begin{array}{l}\text { 1. Teknologi dan peralatan operasional menggunakan } \\
\text { peralatan canggih dan modern. }\end{array}$ & $\begin{array}{l}\text { 1. Ramai pada saat hari libur dan akhir pekan } \\
\text { saja }\end{array}$ \\
\hline $\begin{array}{l}\text { 2. Letak perusahaan sangat strategis karena terletak } \\
\text { dipusat kota }\end{array}$ & 2. Harga atau tarif yang relatif mahal \\
\hline 3. Penampilan berih, rapi, dan wangi menjadi prioritas & $\begin{array}{l}\text { 3.Semangat kerja karyawan yang kurang } \\
\text { konsisten }\end{array}$ \\
\hline 4. Memiliki SDM yang berkompetensi dan bersaing & $\begin{array}{l}\text { 4.Sering terjadi kesalahpahaman dengan } \\
\text { pengelolah lainnya }\end{array}$ \\
\hline $\begin{array}{l}\text { 5. Peralatan pendukung dan inventaris selalu } \\
\text { diutamakan }\end{array}$ & 5. Sistem yang sering tidak berfungsi \\
\hline 6. Perusahaan memiliki nama yang baik & $\begin{array}{l}\text { 6. Banyak karyawan senior dan berpengalaman } \\
\text { mengundurkan diri }\end{array}$ \\
\hline 7. Struktur manajemen yang solid dan profesional & $\begin{array}{l}\text { 7. Pengajuan kebutuhan operasional dan logistik } \\
\text { cenderung lam }\end{array}$ \\
\hline
\end{tabular}

\begin{tabular}{|c|c|c|}
\hline $\begin{array}{l}\text { Peluang } \\
\text { Opportunities } \\
\text { (O) }\end{array}$ & $\begin{array}{l}\text { Strategi } \\
\text { (SO) }\end{array}$ & $\begin{array}{c}\text { Strategi } \\
\text { (WO) }\end{array}$ \\
\hline $\begin{array}{l}\text { 1. Kontrak kerjasama } \\
\text { dengan manajemen } \\
\text { gedung diperbaharui }\end{array}$ & $\begin{array}{l}\text { 1. meningkatkan semangat kerja dan } \\
\text { mengikuti peraturan dan ketentuan } \\
\text { baik yang ditetapkan perusahaan } \\
\text { maupun manajemen gedung. } \\
(\mathrm{S} 3, \mathrm{~S} 4, \mathrm{~S} 5, \mathrm{O} 1, \mathrm{O} 2, \mathrm{O} 3, \mathrm{O} 4, \mathrm{O} 5)\end{array}$ & $\begin{array}{l}\text { 1.Bekerjasama dengan pengelolah lainnya } \\
\text { untuk bersama-sama saling } \\
\text { mempromosikan dengan free parking bagi } \\
\text { pelanggan membeli produk yang } \\
\text { ditawarkan (W1) }\end{array}$ \\
\hline $\begin{array}{l}\text { 2. kebutuhan } \\
\text { kepengolahan parkir } \\
\text { meningkat }\end{array}$ & $\begin{array}{l}\text { 2. Mengadakan peralatan canggih } \\
\text { dan modern untuk mendukung dan } \\
\text { mempermudah operasional }(\mathrm{S} 5, \mathrm{O} 6 \text {, } \\
\mathrm{O} \text { ) }\end{array}$ & $\begin{array}{l}\text { 2.Membangun komunikasi dan kerjasama } \\
\text { guna mempererat hubungan antar } \\
\text { pengelolah. (W4) }\end{array}$ \\
\hline $\begin{array}{l}\text { 3. Tingkat daya beli } \\
\text { masyarakat } \\
\text { meningkat }\end{array}$ & & $\begin{array}{l}\text { 3.meng-upgrade sistem dan peralatan } \\
\text { dengan yang modern dan } \\
\text { canggih.(W5,06,07) }\end{array}$ \\
\hline $\begin{array}{l}\text { 4. Gaya hidup anak } \\
\text { milenial yang suka } \\
\text { liburan di mall }\end{array}$ & & $\begin{array}{l}\text { 4. Refresment dan konseling permasalahan } \\
\text { karyawan (W6) }\end{array}$ \\
\hline $\begin{array}{l}\text { 5. Sering diadakan } \\
\text { event (perayaan) } \\
\text { penting dan } \\
\text { pertemuan besar di } \\
\text { mall }\end{array}$ & & 5.pengajuan logistik bisa lebih dini. (W7) \\
\hline $\begin{array}{l}\text { 6. Dipercaya } \\
\text { masyarakat memiliki } \\
\text { sistem dan } \\
\text { pelayanan yang baik }\end{array}$ & & \\
\hline $\begin{array}{l}\text { 7. Proyeksi } \\
\text { manajemen gedung } \\
\text { untuk menggunakan } \\
\text { pelayanan teknologi }\end{array}$ & & \\
\hline
\end{tabular}




\begin{tabular}{|c|c|c|}
\hline digital & & \\
\hline \multicolumn{1}{|c|}{$\begin{array}{c}\text { Ancaman } \\
\text { Threats } \\
(\mathrm{T})\end{array}$} & \multicolumn{1}{|c|}{$\begin{array}{c}\text { Strategi } \\
\text { (ST) }\end{array}$} & \multicolumn{1}{c|}{$\begin{array}{c}\text { Strategi } \\
\text { (WT) }\end{array}$} \\
\hline $\begin{array}{l}\text { 1. Putus kontrak } \\
\text { kerjasama dengan } \\
\text { manajemen gedung }\end{array}$ & $\begin{array}{l}\text { 1.berkoordinasi pada manajemen } \\
\text { gedung apa saja yang dilakukan. (T1) }\end{array}$ & $\begin{array}{l}\text { 1.Penekanan pada SOP dan etos kerja yang } \\
\text { baik. (W3, T1, T5) }\end{array}$ \\
\hline $\begin{array}{l}\text { 2. Rebutan lahan } \\
\text { parkir dengan para } \\
\text { oknum ormas }\end{array}$ & $\begin{array}{l}\text { 2.Memaksimalkan SDM, infrastruktur } \\
\text { dan teknologi. (S1,S4,S5) }\end{array}$ & $\begin{array}{l}\text { 2.Tinjau tarif \& pajak lalu konsultasi ke } \\
\text { pihak berwenang.(W2,T6) }\end{array}$ \\
\hline
\end{tabular}

Sumber : Hasil Olah Data, 2019

\section{KESIMPULAN}

Berdasarkan pada hasil penelitian dan penganalisisan yang telah dilakukan dapat dikelompokkan kesimpulan berdasarkan lingkungan perusahaan dan strategi utama antara lain sebagai berikut :

1. Berdasarkan lingkungan internal perusahaan

Dari matrik Internal Factory Evaluation (IFE) menghasilkan jumlah nilai tertimbang sebesar 2,94. Berdasarkan pada skala 4 nilai tersebut berada pada posisi yang lemah walaupun hanya sedikit saja untuk bisa berada diposisi yang kuat. Tindakan pada posisi ini antara lain menjaga semangat dan kinerja karyawan serta menaati SOP (Standard Operational Procedur) perusahaan, pengadaan sistem dan peratan modern untuk mendukung operasional dan kebutuhan sesuai zaman, menjalin komunikasi kepada pihak manajemen gedung dan penyewa gedung (tenant).

2. Berdasarkan lingkungan eksternal perusahaan

Matrik Eksternal Factory Evaluation (EFE) menghasilkan nilai tertimbang jumlah nilai tertimbang sebesar 2,88. Posisi ini sama dengan posisi matrik IFE yaitu samasama lemah namun kecenderungannya kuat. Pada lingkungan eksternal ini yang perlu ditingkatkan antara lain : Menjalin komunikasi dengan pihak luar seperti organisasi masyarakat dan pejabat berwenang dan melakukan efisiensi terhadap biaya operasional.

3. Berdasarkan profil persaingan

Pada hasil penelitian pada matrik CPM (Matrik profil Pesaing) yang memiliki Faktor Penentu Keberhasilan (FPK) pada analisisnya sehingga dihasilkan data sebagai berikut PT. Centrepark Citra Corpora sebesar 3,52, PT Secure Parking Indonesia 
sebesar 3,30 dan PT VIP Parking sebesar 2,86. Melihat persaingan dari ketiga perusahaan pengelolah perparkiran sangat ketat dan saling berpotensi mendahului, maka PT. Centrepark Citra Corpora harus mempunyai strategi yang tepat dalam menghadapin persaingan tersebut.

4. Berdasarkan Strategi Prioritas

Strategi Prioritas merupakan hasil akhir dan menjadi kesimpulan akhir dari penelitian adapun Strategi tersebut antara lain :

a. Strategi Pengembangan Pasar. Langkah yang dilakukan antara lain :

1. Menjaga semangat kerja dan menaati peraturan perusahaan (SOP)

2. Menjalin komunikasi dengan berbagai pihak baik manajemen gedung maupun pengelolah (tenant) yang ada.

3. Berkomunikasi dengan pejabat berwenang mengenai tarif parkir

b. Strategi Pengembangan Produk, langkah yang dilakukan antara lain :

1. Pengadaan sistem dan peralatan yang modern dan canggih

2. Peningkatan performa dan pelayanan

c. Strategi Penetrasi Pasar, langkah yang dilakukan antara lain:

1. Melakukan promosi dan iklan perusahaan secara berkala

2. Memaksimalkan fungsi Sumber Daya Manusia (SDM) dan pembaharuan atau perawatan infrastruktur yang ada.

\section{REFERENSI}

Arikunto, Suharsimi. (2009). "Prosedur Penelitian Suatu Pendekatan Praktik”, Jakarta: Rineka Cipta

David, Fred R (2010), “ Manajemen Strategik Konsep-konsep”. Jakarta, Salemba Empat.

Laudon, Kenneth \& Laudon, Jane.(2013). Sistem Informasi Manajemen, Edisi ke-13, Jakarta: Salemba Empat.

Nazir, Mohammad. (2005) Metode Penelitian. Jakarta : Ghalia Indonesia

Porter, Michael E dalam Harvard Business Review (2016). Tentang Definisi Manajemen Strategi

Sutanto, AB. (2017). Manajemen Strategik Komprehensif, Edisi ke-16, Jakarta: Salemba Empat.

Siagian, Sondang P, (2007). Teori Dan Praktek Pengambilan Keputusan, Jakarta: Tema Baru. 
Swastha, Basu. \& Sukotjo, Ibnu. (2010). Pengantar Bisnis Modern, Yogyakarta: Liberty.

Sugiyono. (2011). Metode Penelitian Pendidikan (Pendekatan Kuantitatif, Kualitatif Dan $R \& D)$. Bandung: Alfabeta.

Wheelan \& Hunger. Strategic Manajemen and Business Policy Massachuset, (http://proeunthat.files.wordpress.com) 